Decolonial Love 



\title{
Decolonial Love
}

Salvation in Colonial Modernity

\author{
Joseph Drexler-Dreis
}

F O R D A U N I VERS I T Y PRES S

New York 2019 
Copyright (C) 2019 Fordham University Press

All rights reserved. No part of this publication may be reproduced, stored in a retrieval system, or transmitted in any form or by any means-electronic, mechanical, photocopy, recording, or any other-except for brief quotations in printed reviews, without the prior permission of the publisher.

Fordham University Press has no responsibility for the persistence or accuracy of URLs for external or third-party Internet websites referred to in this publication and does not guarantee that any content on such websites is, or will remain, accurate or appropriate.

Fordham University Press also publishes its books in a variety of electronic formats. Some content that appears in print may not be available in electronic books.

Visit us online at www.fordhampress.com.

Library of Congress Cataloging-in-Publication Data

Names: Drexler-Dreis, Joseph, author.

Title: Decolonial love : salvation in colonial modernity / Joseph Drexler-Dreis.

Description: First edition. I New York, NY : Fordham University Press, 2019. I Includes bibliographical references and index.

Identifiers: LCCN 2018024884| ISBN 9780823281886 (cloth : alk. paper) I ISBN 9780823281879 (pbk. : alk. paper)

Subjects: LCSH: Liberation theology. I Love-Religious aspects-Christianity.

| Baldwin, James, I924-I987. I Fanon, Frantz, I925-196r. | Postcolonial theology.

Classification: LCC BT83.57 .D74 2019 I DDC 26r.8-dc23

LC record available at https://lccn.loc.gov/2018024884

Printed in the United States of America

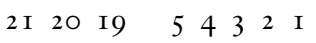

First edition 
for LaToya and Malcolm 
